\title{
A Study on the Relationship Between Mean Years of Schooling, Literacy Skills Level of the Countries, and Their Level of Democratic Development
}

\author{
Ayşe Ottekin Demirbolat ${ }^{1, *}$ \\ ${ }^{1}$ Department of Educational Administration, College of Education, Gazi University, Ankara, Turkey \\ *Correspondence: Department of Educational Administration, College of Education, Gazi University, Ankara, \\ Turkey. E-mail: ademir@gazi.edu.tr
}

Received: January 2, 2019

Accepted: February 9, 2019 Online Published: February 15, 2019

doi:10.5430/wje.v9n1p145

URL: https://doi.org/10.5430/wje.v9n1p145

\begin{abstract}
This study's objective is to examine the relationship between the mean years of schooling, level of adult literacy skills, and democratic development levels. The study was designed as a relational survey model. The analytics employed is the path analysis, which tests the existence of causal relationship between the variables. The statistical analysis indicates that a significant and strong relationship exists between the mean years of schooling and adult literacy skills and further that a significant, medium level, relationship is present between the countries' adult literacy skills and their democratic development levels. Moreover, literacy skills create a significant mediation impact on the relationship between the mean years of schooling and democratic development level. Also significant is the indirect impact of the nations' mean years of schooling on their democratic development levels. Countries seeking to sustain and protect participative and deep democracy may need to review their formal and informal education policies. Therefore, it may be especially necessary to attach greater importance to cognitive-verbal processes in formal education institutions as a departure point of action.
\end{abstract}

Keywords: participatory political culture, mean years of schooling, literacy skills, democratic development

\section{Introduction}

Political system of societies is a derivative of their political cultures. Political culture is the series of beliefs and values that play a role in the political life of a country. It structures the political processes and determines the political ideals and norms (Lane \& Ersson 2007, p.32). The most widely known political culture theory was developed by Almond and Verba (1963) according to whom, political culture could be studied in terms of three orientations, namely: "cognitive," "affective," and "evaluational". An individual with "cognitive" orientation would at the minimum, be cognizant of the political institutions of her/his society, that with "affective" orientation would have an affective perception about the political structure, events, and personae, where as an individual with "evaluational" orientation would not only have knowledge as regards the political phenomena and personae, but would also have critical skills. The three levels of political civic culture breed three corresponding types of political administrative culture: "parochial" "dependent" and "participatory". The parochial culture fosters a centralist, traditional, administrative structure, the dependent culture gives rise to an authoritative a centralist administrative one while the participatory culture sustains a developed democratic administrative structure. Democratic societies are sustained, only if a civic majority exists which has internalized "participatory" and "evaluational" political culture.

Political cultures are shaped and ingrained by experience in both public and individual contexts. A democratic participatory culture is invigorated by institutions, rules, and principles in the public-administrative context, and by the experiences of civic democratic participation in the individual context. However, the development of democratic political life and its acquisition of legitimacy depends primarily on the institutions (Lane \& Ersson, 2003). While the institutions determine how the political power would be exercised, the political actors seek to have the institutions under their control (Acemoğlu \& Robinson, 2007). Educational institutions are on top of the list of institutions that the political actors seek to control (Demirbolat, 2012). However, they are the least willing to hear the voice of the groups outside the dominant culture (Apple \& Buras, 2006 of all to Lane \& Ersson, 2007: p 22). This would not yet change the 
fact that education is still the most effective tool of change in social life.

Democracies in societies with higher levels of education are more resilient compared to those with lower levels. Several empirical studies confirm this (Almond \& Verba, 1963; Barro, 1997; Barro \& Lee, 2000; Demirbolat, 2018; Papaioannou \& Siourounis 2008; Inkeles, 1983; Lipset, 1959-1960; Marshall \& Jaggers 2010; Glaeser, Ponzetto \& Shleifer, 2006; Torney-Purta, Lehmann, Oswald \& Schulz, 2001). Almond and Verba (1963) asserted that education is an important factor as regards the formation of democratic civic culture and participation. They claimed that the individuals with no or limited education have, as political actors, different attributes than those with higher education. There is a significant difference in effect between being an effective participant and being merely a participant subject. While the effective participant demonstrates "a conscious way of participation oriented to changing and transforming", the mere participant subject not having the "deep reflection that characterizes democracy" merely affirms. Furthermore, the value of democratic participation is associated not only with the quantity volume of the participation act, but at the same time with the quality level. Hence, democracy level of societies should not be seen only as a derivative of their mean years of schooling, but also of the content and quality of education made available.

Taking into consideration that educational programs are used by political institutions to maintain the power relationships within the society and that they are conveyed to societies through the schooling process (Olssen, Codd, \& O'Neill, 2004), the importance of the contents of education is beyond debate.

Educational systems may raise conscious, democrat participants who act at evolutional level, subject participants, who act only at perceptive and affective level, depending upon the objectives of the educational systems. A given educational system may aim at teaching, and conveying knowledge while another one may consider acquisition of intellectual skills an important and prioritized objective. Intellectual skills include literacy skills that encompass acquiring knowledge from different sources, differentiating truth from ideas, and rationally processing, evaluating, and criticizing information.

In most of the modern societies, the educational system is controlled by the state and thus the continuance of the power relations within society is ensured. The educational policies and educational programs are transformed into mediator objects of the official state discourse (Olssen, Codd, \& O'Neill, 2004). Yet, despite of all this, such discourses have a limit that starts with the individual. According to a research by Dee (2004), the more education the individual receives, the higher is the voting and newspaper-reading rate. This is partly associated with the cognitive competencies acquired by education in processing complex political information, decision making, and overcoming bureaucratic and technical obstacles.

Democracy is a matter of communication (Dewey, 1938). There are several studies, which address the effects of communication on the youth becoming participant citizens. Studies by Mossberger, Tolbert, \& McNeal (2008); Bennett (2008); Quintelier \& Vissers (2008); Smith, Schlozman, Verba \& Brady (2009); and McLeod \& Shah (2009) claim that digital media provided not only new opportunities for the youth's participation in political and civilian life, but also increased it. In general, the shared contention of these studies is that communication competence is a civic life competence, which ensures political participation.

In the present study, the concept of literacy skills is preferred over the communications skills or communicative competence. Literacy skills denote the ability to accurately understand written texts and provide proper responses in conformity with these texts (PIAAC, 2016). Although literacy skills are indeed communicative skills, they allude to a process so specific that it cannot be limited to that. Communicative skills may invigorate the participative motive of the youth in contexts of developing arguments, expressing views, handling disagreements, and comprehending complex matters. However, the quality of participation is limited by the quality of literacy skills. Yet, studies on the effect of communicative skills on political socialization discuss only the quantitative findings as regards the increase in the level of participation. In contradistinction to those, the objective of the present study is to discuss qualitative aspects of participation in the democratic process.

In this text, it is of importance that literacy skills are taken as the starting point of a communicative act. The purpose of a reading act is to transform the messages encoded in the form of letters into meaning. Reading skills denote extracting meaning from and interpreting a text that is being read (Grabe \& Stoller, 2002). Then determine the quality of both the process and it's end product. The end-product is the inferred meaning, and analysis oriented to discovery of meaning, comments, criticisms, and discussions that ensue. Having been oriented to comprehension such skills are important not only for the development of citizen behavior needed by the democratic systems but also for the attainment of the objectives of the education system. It is here deemed in the context of the above discussion that there is a relationship between the political democratic systems of the countries and mean years of schooling, and the level of literacy skills of adults. 
The present study's objective is to test the theoretical model as hereby developed (Figure 1) and to examine the relationship between the mean years of schooling, level of adult literacy skills, and democratic development levels. Accordingly, three research hypotheses were developed:

$\mathrm{H}_{1}$ : There is a positive relationship between the mean years of schooling of countries and their level of adult literacy skills.

$\mathrm{H}_{2}$ : There is a positive relationship between the level of adult literacy skills of countries and their democratic development levels.

$\mathrm{H}_{3}$ : The level of adult literacy skills of countries mediates the relationship between the mean years of schooling and democratic development level.

\section{Method}

\subsection{Research Model}

Having aimed at investigation the relationship between the countries' mean years of schooling, levels of reading skills, and democratic development levels, the present study was designed as a relational survey model. This method is used to establish the cause-effect relationship between two or more variables (Christensen, Johnson \& Turner, 2015). The analytics employed is the Path Analysis which tests the existence of causal relationships between the variables (Fraenkel \& Wallen, 2009). The model is given in Figure 1. It takes the countries' mean years of schooling as the independent variable, the reading skills level as the mediator one and democratic development level as the dependent variable.

\subsection{Population and Sample}

The research population consists of the 33 countries jointly included in the Democracy Index (2016), Human Development Report (2016), and Programme for the International Assessment of Adult Competencies (PIAAC, 2016). The countries included in the three indexes are given in Table 1.

\subsection{Data}

The data was obtained from the three above mentioned international reports. Democracy index includes five sub-dimensions: electoral process and pluralism, functioning of government, political participation, political culture, and civil liberties. The Human Development Report consists of four sub-dimensions: life expectancy at birth, expected years of schooling, mean years of schooling, and gross domestic product (GDP) per capita. The Programme for the International Assessment of Adult Competencies (PIAAC, 2016) index is composed of three sub-dimensions: literacy, numeracy and problem solving in technology-rich environments. Of these, only the Democracy Index and the sub-dimensions of mean years schooling from the Human Development Report and Literacy from the Assessment of Adult Competencies are used in the study.

\subsection{Data Analysis}

Data analysis was performed in two stages. First the Pearson Correlation Analysis was conducted to find the degree of relationships between the variables. In the second stage, the theoretical model was tested by path analysis. SPSS and AMOS statistical software packages were used for the analytics.

The goodness of fit indexes was calculated. These indexes were as follows: GFI (goodness-of-fit index), AGFI (adjusted goodness-of-fit index), TLI (Tucker-Lewis index), RMSEA (root mean square error of approximation), $\chi^{2}$ (Chi square), $\mathrm{df}$ (degrees of freedom), and $\chi^{2} / \mathrm{df}$ ratio. The coefficient varies between 0 and 1 in the GFI, AGFI, and TLI indexes. Although there is no complete match, literature provides that a coefficient above 0.85 (Anderson \& Gerbing, 1984) or 0.90 (Kline, 2011; Schumacker \& Lomax, 1996) is considered a good fit. Similarly, in RMSEA, which gives the margin of error between the observed and generated matrices. The coefficient also varies between 0 and 1, but unlike GFI and AGFI, values closer to 0 are considered necessary for a fit; accordingly values equal to or lower than 0.05 suggest fitness. As regards the $\chi^{2} / \mathrm{df}$ rate, values between 2 and 5 denote good fit (Sümer, 2000) and values lower than 2 suggest perfect fit (Kline, 2011; Jöreskog \& Sörbom, 2001).

There are positive, statistically significant relationships between the countries' mean years of schooling, adult literacy skills, and democratic development levels. There is a significant and powerful relationship between mean years of schooling and adult literacy skills $(\mathrm{r}=.79, p \leq .01)$. This verifies, Hypothesis 1 . There is also a statistically, significant relationship, albeit not a strong relationship, between the countries' level of adult literacy skills and democratic development levels and thus Hypothesis 2 is also verified $(\mathrm{r}=.37, p \leq .05)$. 
Structural equation modelling was used in order to examine the mediation effect of the levels of adult literacy skills on the relationship between the countries' mean years of schooling and democratic development levels. The standardized path model is provided the goodness of fit indexes are $(\chi 2 / \mathrm{df}=1.296$; RMSEA $=.096$; CFI $=.991$; $\mathrm{AGFI}=.845 ; \mathrm{TLI}=.974)$ in Figure 2. Hence, the direct and indirect impacts of the independent variables are given in Table 2. Hypothesis 3, that the level of adult literacy skills of countries mediates the relationship between the mean years of schooling and democratic development level is verified.

The standardized path coefficients provided in Table 3 suggest that adult literacy skills directly, and statistically significantly, predict the countries' democratic development levels $(\beta=.37)$. Besides, the countries' levels of adult literacy skills mediate the relationship between the mean years of schooling and democratic development levels. The indirect impact of the nations' mean years of schooling on democracy development levels is also significant ( $\beta$ $=.29$ ).

\section{Discussion}

The statistical analysis indicates that a significant and strong relationship exists between the mean years of schooling and adult literacy skills and further that a significant, medium level, relationship is present between the countries' adult literacy skills and their democratic development levels. Moreover, literacy skills create a significant mediation impact on the relationship between the mean years of schooling and democratic development level. Also significant is the indirect impact of the nations' mean years of schooling on their democratic development levels. The model presented previously is verified.

The outcome of the analysis as regards the indirect effect of the countries' mean years of schooling on their democratic development levels is in support of the findings of various studies (Almonda \& Verba, 1963; Barro, 1997; Barro \& Lee, 2000; Demirbolat, 2018; Inkeles, 1983; Papaioannou \& Siourounis, 2008; Lipset, 1959, 1960; Marshall \& Jaggers, 2010; Glaeser, Ponzetto, \& Shleifer, 2006). The strong relationship between the countries' mean years of schooling and democratic development levels, and the finding that the countries' levels of adult literacy skills directly and significantly predict their democratic development levels are indirectly supported by the studies of McLeod (2000); Mossberger, Tolbert, \& McNeal (2008); Bennett (2008); McLeod \& Shah (2009). Their support is indirect because the relevant studies are on the relationship between the youth's communicative skills and participative processes, while the present study focuses on the relationship between the countries' democratization levels and their literacy skills. Unlike the studies, which were conducted in the context of communicative processes, and which tended to evaluate the intensity and form of participation processes, the present study, which is performed in the context of literacy skills, aims to evaluate the quality of such participation and, depending upon that quality, its impact on democracy. Furthermore, although the communicative skills and literacy skills are not substitutable concepts, it was also inferred that these two different contexts were interrelated and complementary concepts.

Formal education and compulsory schooling programs of the countries ensure the acquisition by the citizens such basic skills as literacy and mathematics that are required for active citizenship and participation (Olssen, Codd, \& O'Neill, 2004). However, it is well known that not every educational process is equally effective. There is always the likelihood of failure in attaining general educational objectives as well as the goals of democratic civic education due to inequalities of opportunity in education. Yet, equality of opportunity in education is the most important indicator of the relationship between education and democracy at macro level (Demirbolat, 2012). Overcrowded classrooms, cold school environments, lower levels of parent literacy skills (Hartley, 1989), insufficient school resources (Schneider, 2002), insufficient teachers (Ngussa, 2015), unsafe school environments and lack of sense of belonging (PIRLS, 2016), and inadequacy of students' basic language skills (OECD, 2016; Suskind, 2018) inhibit the children from developing literacy skills. Furthermore, the past experiences of individuals, social backgrounds, and differences in parental political interest, needs, and tendencies constitute other factors that hinder the attainment of equality in civic education goals. However, the survival and sustainability of democracies require an integrated civic majority composed of individuals who have absorbed democratic principles, who are open-minded, sensitive to differences, fair-minded, rational, respectful to reality, and who are able to think critically. Critical thinking denotes the democratic learning process whereby the power relations and social inequalities are brought under scrutiny (Cummins, 1989). It requires high-level skills including analysis, synthesis, and evaluation beyond reading, and cognitive skills (Richard-Amato \& Snow, 1992). Thanks to the high-level skills, citizens come to read and understand the rules concerning the shared community life, raison d'être of such rules, the power levels of individuals in the society, and the attitudes and policies of the government institutions towards human rights. In brief, the achievement of meaningful outputs of democratic education requires prior cognitive competence, which is 
associated with meaning and content knowledge (O’Shea, 2003).

Real democracy is a matter of deep reflection (Willinsky, 2002). Individuals can think about the contents thanks to the words and images in one's mind generated by them about the contents. Individuals interpret what is happening in their inner worlds and their environment by means of words, and convey her/his thoughts to others again thanks to the words. In that context, adequate levels of reading, writing, listening, and speaking skills on the part of students, in the language of education positively affect their ability to think, understand, interpret, and express themselves in that language. As the literacy skills of individuals improve with the improvement of their cognitive awareness the likelihood of their democratic actions arising at an evolutional level subsequent to deep reflection, rather than accruing at perceptive or affective levels increase.

\section{Conclusion and Suggestion}

Countries seeking to sustain and protect participative and deep democracy may need to review their formal and informal education policies. Especially the easily accessed, easily consumed populist information mess associated with the developments in communication technologies may complicate acquisition and retention of independent, scientific, and deep reflective thinking and reading skills. Therefore, it may be especially necessary to attach greater importance to cognitive-literacy processes in formal education institutions as a departure point of action. Literacy skills are important not only in the context of educational stages but also in the context of forming lifelong habits and in the development of political literacy. Dewey (1916) pointed out that democracy was at the same time a lifelong, broad-based learning process. In that context, developing policies towards lifelong learning processes that encompass all the individuals in the society and popularizing an active and participatory citizenship program (O'Shea, 2003) may be of great importance for securing the future and sustainability of democracies. Democratic goals, which may not have been attained in formal education due to inequality of opportunities may yet be attained by informal adult education.

\section{References}

Acemoğlu, D., \& Robinson, J. A. (2007). Economic origins of dictatorship and democracy. New York: Cambridge University Press.

Almond, G. A., \& Verba, S. (1963). The Civic culture, political attitudes and democracy in five nations, princeton. NJ: Princeton Universite Press. https://doi.org/10.1515/9781400874569

Anderson, J. C., \& Gerbing, D. (1984). The effect of sampling error on convergence, improper solutions, and goodness-of-fit indices for maximum likelihood confirmatory factor analysis. Psychometrika, 49, 155-173. https://doi.org/10.1007/BF02294170

Barro, R. J. (1997). Determinants of Democracy. Development Discussion Paper. Harvard Institute for International Development, Harvard University, (570), January.

Barro, R. J., \& Lee, J. (2000). International data on educational attaintment updates and implication. National Bureau of Economic Research Working Paper Series. Retrieved from http://www.nber.org/papers/w7911

Bennett, W. L. (2008). Changing citizenship in the digital age. In W. L. Bennett (Ed.), Civic Life Online, Learning how Digital Media can Engage Youth, Massachusetts US: MIT Press.

Christensen, L. B., Johnson, R. B., \& Turner, L. A. (2015). Araştırma yöntemleri: Desen ve analiz (A. Aypay, Çev.). Ankara: An1.

Cummins, J. (1989). The sanitized curriculum: Educational disempowerment in a nation at risk. In D. M. Johnson \& d. H. Roen, (Eds.), Richness in writing Empowering ESL students (p. 19-38). White Plains, NY: Longman.

Dee, T. S. (2004). Are there civic returns to education? Journal of Public Economics, 88, 1697-1720. https://doi.org/10.3386/w9588

Demirbolat, O. A. (2012). The relationship between democracy and educations. Bentham eBooks: Dubai, UAE. https://doi.org/10.2174/97816080537111120101

Demirbolat, O. A. (2018). Democracy, Human Development, and Happiness Indices as Precursors of International Student Success. Journal of Education and Learning; 7(1), 237-244. https://doi.org/10.5539/jel.v7n1p237

Dewey, J. (1916). Democracy and education. New York: Macmillan.

Dewey, J. (1938). Education and experience. New York: Macmillan. 
Fraenkel, J. R., \& Wallen, N. E. (2009). How to design and evaluate research in education. New York: McGraw-Hill Higher Education.

Glaeser, E., G. Ponzetto, \& A. Shleifer (2006). Why does democracy need education? J Econ Growth, 12(2), 77-99. https://doi.org/10.1007/s10887-007-9015-1.

Grabe, W., \& Stoller, F. L. (2002). Teaching and researching reading. Harlow, England: Pearson Education.

Inkeles, A. (1983). Exploring individual modernity. New York: Columbia University Press.

Jöreskog, K., \& Sörbom, D. (2001). LISREL 8.51. Mooresvile: Scientific Software.

Kline, R. B. (2011). Principles and practice of structural equation modeling. NY London: The Guilford Press.

Lane, J. E., \& Ersson, S. (2003). Democracy a comparative approach. New York: Routledge.

Lane, J. E., \& Ersson, S. (2007). Culture and politics: A comparative approach (2nd ed.). Burlington: Ashgate Publishing Company.

Lipset, S. M. (1959). Some social requisites of democracy: Economic development and political legitimacy. American Political Science Review, 53(1), 69-105. https://doi.org/10.2307/1951731

Lipset, S. M. (1960). Political man; the social bases of politics. Garden City, N.Y: Doubleday.

Marshall, M. G., \& Jaggers K. (2010). Polity IV project: Political Regime characteristics and transitions 1800-2008. University of Maryland, College Park, MD.

McLeod, G. (2000). Beyond Use Case. Proceedings of the Fifth Caise/IFIP8.1 International Workshop on Evaluation of Modeling Methods in Systems Analysis and Design, Stockholm, Sweden.

McLeod, J. M., \& Shah, D. V. (2009). Communication and political socialization: Challenges and opportunities for research. Political Communication, 26, 1-10. https://doi.org/10.1080/10584600802686105

Mossberger, K., Tolbert, C. J., \& McNeal, R. S. (2008). Digital citizenship: The Internet, society, and participation. London, England: MIT Press.

Ngussa, N. K. (2015). Factors contributing to low literacy among primary school pupils: A case of Mkuranga District, Tanzania (Doctoral dissertation). Sokoine University of Agriculture.

O'Shea, K. (2003). Developing a shared understanding. DGIV/EDU/CIT (2003) 29, Council of Europe, Strasbourg.

OECD. (2016). Skills Matter: Further Results from the Survey of Adult Skills. OECD Skills Studies, OECD Publishing, Paris. https://doi.org/10.1787/9789264258051-en

Olssen, M., Codd J., \& O’Neill A. (2004). Education policy globalization, citizenship \& democracy. London: SAGE Publications.

Papaioannou, E., \& Siourounis G. (2008). Economic and social factors driving the third wave of democratization. Journal of Comparative Economics, 36, 365-387. https://doi.org/10.1016/j.jce.2008.04.005

Quintelier, E., \& Vissers, S. (2008). The effect of Internet use on political participation: An analysis of survey results for 16-year-olds in Belgium. Social Science Computer Review, 26(4), 411-427. https://doi.org/10.1177/0894439307312631

Richard-Amato, P. A., \& Snow, M. A. (1992). The multicultural classroom: Readings for content-Area teachers. Reading, MA: Addison-Wesley.

Schneider, M. (2002). Do school facilities affect academic outcomes? Retrieved from http://www.ncef.org/pubs/outcomes.pdf

Schumacker, R. E., \& Lomax, R. G. (1996). A beginner's guide to structural equation. Mahwah, NJ: Erlbaum.

Smith, A. W., Schlozman, K. L., Verba, S., \& Brady, H. (2009). The Internet and civic engagement. Washington, DC: Pew Internet \& American Life Project. Retrieved from http://www.pewinternet.org/files/old-media/Files/Reports/2009/The\%2520Internet\%2520and\%2520Civic\%252 0Engagement.pdf

Sümer, N. (2000). Yapısal eşitlik modelleri: Temel kavramlar ve örnek uygulamalar. Türk Psikoloji Yazılarl, 3(6), 49-74.

Suskind, D. (2018). Otuz milyon kelime. İstanbul: Buzdağı. 
Torney-Purta, J., Lehmann, R., Oswald, H., \& Schulz, W. (2001). Citizenship and education in twenty-eight countries. Amsterdam: International Association for the Evaluation of Educational Achievement (IEA).

Willinsky, J. (2002). Democracy and Education: The missing link may be ours. Harvard Educational Review, 72(3), 367-392. https://doi.org/10.17763/haer.72.3.0nj018h638677r24 